\title{
Efektivitas Daya Hambat Disinfektan Klorin terhadap Bakteri Escherichia Coli Penghasil Extended Spectrum Beta Lactamase
}

\author{
Krisna Fernanda Suryaputra ${ }^{1}$, Donna Mesina Rosadini Pasaribu ${ }^{2}$, Ade Dharmawan ${ }^{2}$ \\ ${ }^{1}$ Fakultas Kedokteran dan Ilmu Kesehatan, Universitas Kristen Krida Wacana, Jakarta, Indonesia \\ ${ }^{2}$ Departemen Mikrobiologi Fakultas Kedokteran dan Ilmu Kesehatan, Universitas Kristen Krida \\ Wacana, Jakarta, Indonesia \\ Alamat Korespondensi: donna.pasaribu@ukrida.ac.id
}

\begin{abstract}
Abstrak
Escherichia coli termasuk salah satu bakteri yang mampu beradaptasi dan mengembangkan resistensinya terhadap antibiotika $\beta$-laktam. Kemampuannya tersebut ditentukan oleh adanya enzim Extended Spectrum Beta-Lactamase (ESBL). Salah satu bahan yang dapat digunakan untuk pengendalian penyebaran E.coli penghasil ESBL adalah klorin. Penelitian ini bertujuan untuk mengetahui efektivitas daya hambat disinfektan klorin terhadap E. coli penghasil ESBL. Metode penelitian dilaksanakan dengan pencelupan batang gelas ke suspensi E.coli selama 5, 10 dan 15 menit, batang gelas tersebut dicelupkan ke dalam larutan klorin $(0,05$ sampai dengan $5 \% \mathrm{w} / \mathrm{v}$ ). Kemudian batang gelas tersebut dicelupkan secara berturut-turut ke phosphate bufer saline (PBS), dan kaldu Mueller-Hinton. Setelah itu, batang gelas digoreskan di medium agar McConkey. Ada atau tidaknya pertumbuhan diamati setelah diinkubasikan selama 24 jam dan pada suhu $37^{\circ} \mathrm{C}$. Hasil penelitian menunjukan seluruh bakteri tidak tumbuh pada seluruh konsentrasi beserta waktu kontaknya, kecuali pada set kedua waktu kontak 15 menit dengan konsentrasi $0,05 \%$, yang diduga karena kontaminasi. Simpulan penelitian menyatakan klorin $0,05 \%$ adalah konsentrasi paling efektif dalam membunuh E. coli penghasil ESBL dengan waktu kontak 5 menit.
\end{abstract}

Kata Kunci: Escherichia coli, ESBL, klorin, waktu kontak

\section{Inhibition Effectivity Test of Chlorine Disinfectant against Escherichia Coli Extended Spectrum Beta Lactamase Bacteria}

\begin{abstract}
Escherichia coli is one of the bacteria that is able to adapt and develop resistance to beta-lactam antibiotics, due to the presence of the Extended Spectrum Beta-Lactamase (ESBL) enzyme. One of the materials that can be used to control the spread of ESBL-producing E. coli is chlorine. This study aimed to determine the effectiveness of chlorine disinfectant against ESBL-producing E. coli. Inhibition tests were carried out by immersing a glass rod into E. coli suspensions for 5, 10 and 15 minutes. Then the glass rod was dipped in chlorine solution $(0.05$, up to $5 \% \mathrm{w} / \mathrm{v})$. Then the glass rod was dipped successively in phosphate buffer saline $(P B S)$ and Mueller-Hinton broth. After that, the rod was streaked on a McConkey agar medium. The presence or absence of growth was observed after a 24 hour incubation at $37^{\circ} \mathrm{C}$. The results showed that all bacteria did not grow at all chlorine concentrations along with their contact time, except for the second set $(0.05 \%$ and 15 mins contact time) which was suspected due to contamination. Results indicated that $0.05 \%$ chlorine is effective in killing ESBL-producing E. coli with a contact time of 5 minutes.
\end{abstract}

Keywords: Escherichia coli, ESBL, chlorine, contact time 


\section{Pendahuluan}

Bakteri Escherichia coli (E. coli) merupakan salah satu contoh bakteri yang terus menerus berevolusi sejak penemuan pertamanya pada tahun 1885. ${ }^{1}$ E. coli sendiri adalah salah satu flora normal dalam tubuh yang berkolonisasi dalam saluran cerna manusia dan hewan. Namun, bakteri ini juga dapat bersifat patogen. ${ }^{2}$ Dari taksonominya, E. coli termasuk dalam famili Enterobacteriaceae dan merupakan bakteri batang Gram negatif tidak berspora, memiliki flagella peritrik, fimbriae, dan kapsul yang mana ketiga hal tersebut juga berperan sebagai antigen, bersifat fakultatif aerob, dapat tumbuh pada suhu $10-37^{\circ} \mathrm{C}$ dan $\mathrm{pH} 7,2$. Bakteri ini dapat tumbuh di berbagai macam media yaitu pada media agar nutrien dan media selektif McConkey karena sifatnya yang dapat memfermentasi laktosa. $^{3-6}$

ESBL adalah suatu enzim yang diproduksi oleh bakteri yang dapat menghidrolisis antibiotik golongan $\beta$-laktam seperti penicillin, sefalosporin, seftazidim, seftriakson, dan sefotaxim. Saat ini, ESBL diklasifikasikan berdasarkan Bush Group dan Ambler Class dan tipe-tipe yang penting secara klinis adalah TEM, SHV, dan CTX-M. ${ }^{7-10}$ Terdapat tiga mekanisme utama dalam resistensi terhadap antibiotik $\beta$-laktam yaitu dengan cara penghancuran langsung antibiotik $\beta$-laktam, perubahan target antibiotik, dan penurunan penyerapan intraseluler. Dari ketiga mekanisme tersebut, penghancuran langsung antibiotik $\beta$ laktam adalah mekanisme yang paling sering terjadi yang melibatkan pemecahan ikatan cincin $\beta$-laktam pada antibiotik, sehingga antibiotik tidak dapat berikatan dengan Penicillin Binding Protein (PBP) dan proses sintesis dinding sel terus berlangsung. ${ }^{11}$

Peningkatan resistensi terhadap antibiotik merupakan masalah di pusat pelayanan kesehatan ataupun di masyarakat yaitu dalam bentuk peningkatan angka kejadian infeksi. Anggraini (2018) menemukan prevalensi bakteri E. coli penghasil ESBL di RSUD Arifin Achmad Pekanbaru sebesar $62,2 \% .{ }^{12}$ Selain itu, produksi antibiotik yang lambat dan peningkatan jumlah bakteri resisten yang semakin cepat, antiseptik dan disinfektan mulai digunakan sebagai strategi pengendalian infeksi. Namun, LeChevallier (1988) dan Chen (2012) menemukan adanya suatu mekanisme resistensi terhadap bahan biosida tersebut. Resistensi ini disebabkan oleh karena adhesi bakteri pada suatu permukaan dan perubahan struktur sel membran yang melindungi bakteri dari paparan bahan biosida. ${ }^{13,14}$ Verspecht
(2019) juga menemukan adanya hubungan antara resistensi antibiotik dengan kejadian resistensi terhadap bahan biosida dimana ditemukan bahwa paparan berulang terhadap bahan biosida menyebabkan konsentrasi hambat minimal bakteri meningkat. Hal ini disebut sebagai resistensi silang (cross-resistance). ${ }^{15}$

Klorin adalah salah satu bahan biosida yang termasuk dalam golongan bahan pelepas halogen. Bahan biosida sendiri merupakan suatu bahan fisik atau kimia yang mempunyai fungsi untuk mengnonaktifkan mikroorganisme. Mekanisme kerja klorin ialah ketika klorin bereaksi dengan air, maka akan dibentuk asam hipoklorus yang merupakan agen oksidasi yang merusak protein pada sel. Oksidasi terjadi pada grup sulfhydryl $(\mathrm{SH})$ dan ikatan disulfida $(\mathrm{S}-\mathrm{H})$ protein enzimatik dan menyebabkan denaturasi. ${ }^{5,7}$ Klorin pada dasarnya digunakan pada konsentrasi rendah pada, pusat pelayanan kesehatan, konsentrasi yang direkomendasikan adalah $0,05-0,07 \%$ untuk disinfeksi peralatan dan 5,25\% untuk disinfeksi alat suntik. Ini dikarenakan efek samping klorin pada konsentrasi tinggi dapat menyebabkan beberapa dampak negatif seperti iritasi hingga nekrosis jaringan. ${ }^{8,9}$

Penelitian mengenai efektivitas disinfektan di Indonesia saat ini masih kurang dilakukan. Oleh karena latar belakang tersebut maka dilakukan penelitian efektivitas disinfektan klorin dengan konsetrasi yang sering ditemukan secara komersial serta yang direkomendasikan dari literatur dengan tujuan mengetahui apakah ada pengaruh relatif konsentrasi disinfektan klorin dengan waktu kontak minimal yang dapat menghambat pertumbuhan bakteri $E$. coli penghasil ESBL. Hasil penelitian diharapkan dapat menambah studi kepustakaan dan dijadikan referensi untuk penelitian selanjutnya mengenai disinfektan serta dapat dijadikan acuan dalam pemilihan disinfektan dalam rangka upaya pengendalian infeksi di pusat pelayanan kesehatan.

\section{Metodologi}

Penelitian ini menggunakan desain penelitian experimental descripsion, dimana suatu kelompok eksperimen akan diberikan perlakuan dan akan dibandingkan dengan kelompok kontrol. Penelitian dilakukan di laboratorium penelitian Fakultas Kedokteran dan Ilmu Kesehatan Universitas Kristen Krida Wacana pada bulan Agustus 2020. Subjek penelitian yang digunakan adalah isolat bakteri Escherichia coli ATCC $^{\circledR} 35218^{\mathrm{TM}}$ yang 
disediakan Departemen Mikrobiologi FKIK UKRIDA yang sudah ditanam dalam agar nutrien.

Prosedur pengujian dilakukan secara aseptis, peralatan yang digunakan untuk pengujian efektivitas klorin, dibebas hamakan. Bakteri Escherichia coli ATCC $^{\circledR} 35218^{\mathrm{TM}}$ dikultur pada media agar McConkey sebagai cadangan dan untuk peremajaan. Disinfektan klorin diencerkan dengan rumus $\mathrm{M}_{1} \mathrm{~V}_{1}=\mathrm{M}_{2} \mathrm{~V}_{2}$, dengan konsentrasi target yaitu $5 \% ; 2,5 \% ; 0,5 \%$; dan $0,05 \%$. Suspensi bakteri dibuat dalam laurtan fisiologis $\mathrm{NaCl} 0,9 \%$ dengan kekeruhan 0,5 mcFarland. ${ }^{11,15-17}$

Penentuan minimum contact time dilakukan dengan prinsip qualitative suspension test. ${ }^{16}$ Pertama dimasukkan 3 batang gelas steril ke dalam suspensi bakteri yang sebelumnya sudah dibuat. Di siapkan disinfektan klorin dengan konsentrasi berbeda-beda antara lain 5\%; 2,5\%; 0,5\%; dan $0,05 \%$. Tiga batang gelas steril dicelupkan ke dalam disinfektan dengan waktu yang berbedabeda antara lain 5, 10, dan 15 menit. Selanjutnya setiap batang gelas dimasukan ke dalam tabung reaksi yang mengandung Phosphate Buffer Saline (PBS) untuk menetralisir kerja antiseptik klorin, kemudian dicelupkan ke dalam tabung reaksi yang mengandung kaldu Mueller-Hinton steril dan diinkubasi selama 24 jam pada suhu $37^{\circ} \mathrm{C}$. Untuk kontrol positif, batang gelas tidak perlu dicelupkan ke disinfektan dan untuk kontrol negatif tidak perlu dicelupkan ke suspensi bakteri dan selanjutnya keduanya dicelupkan ke kaldu Mueller-Hinton dan diinkubasi selama 24 jam dan suhu $37^{\circ} \mathrm{C}$. Setelah 24 jam, diambil 1 ose kaldu Mueller-Hinton, ditanam pada media agar McConkey, dan diinkubasi selama 24 jam pada suhu $37^{\circ} \mathrm{C}$. Hasil pada kaldu Mueller-Hinton dan media agar McConkey dicatat dan dilaporkan. ${ }^{17,18}$ Uji coba dilakukan secara duplo.

\section{Hasil}

Penelitian ini menunjukan bahwa hasil uji waktu kontak pada kaldu Mueller-Hinton tidak ada bakteri yang tumbuh pada semua perlakuan. Sedangkan hasil kultur konfirmasi pada media agar McConeky menunjukkan bahwa pada konsentrasi klorin 5\%; 2,5\%; 0,5\%, dengan waktu kontak 5, 10,15 menit bakteri tidak ada yang tumbuh, tetapi pada konsentrasi klorin $0.05 \%$ dengan waktu kontak 15 menit ditemukan ada bakteri yang tumbuh. Semua uji pada kontrol positif tumbuh, dan kontrol negatif tidak tumbuh. Dari hasil percobaan dapat dilihat bahwa konsentrasi disinfektan $0,05 \%$ sudah dapat membunuh bakteri
E. coli penghasil ESBL dengan waktu kontak 5 menit.

\section{Pembahasan}

Uji yang dilakukan untuk menilai efektivitas disinfektan klorin adalah dengan menilai minimum waktu kontak suatu disinfektan dengan bakteri menggunakan prinsip suspension test yang juga merupakan salah satu metode untuk menilai efektivitas bahan biosida. ${ }^{16}$ Konsentrasi klorin yang digunakan pada penelitian ini $(5 \% ; 2,5 \%$; $0,5 \%$, dan $0,05 \%$ ) adalah konsentrasi yang sering digunakan secara komersial dan direkomendasikan di pusat pelayanan kesehatan.

Pada set 1 dan set 2, hasil menunjukan bahwa pada seluruh konsentrasi dan waktu kontak yang diujikan hasilnya jernih pada kaldu MuellerHinton. Kekeruhan pada media kaldu sering diaplikasikan untuk menentukan pertumbuhan suatu bakteri yang terpapar bahan antimikroba. Kekeruhan sendiri adalah kemampuan suatu partikel mengapung untuk membelokkan dan memantulkan cahaya kembali ke mata pengamat. ${ }^{11}$ Kaldu jernih pada media Mueller-Hinton dikonfirmasi kembali dengan melakukan subkultur pada media agar McConkey. Secara keseluruhan, hasil menunjukan bahwa tidak ada koloni bakteri yang tumbuh pada media agar McConkey. Hasil ini menunjukan bahwa bakteri tidak tumbuh pada seluruh konsentrasi klorin dengan waktu kontak yang diujikan.

Terjadi 2 error pada penelitian ini. Pada kontrol positif set 1 konsentrasi klorin $0,5 \%$, kaldu Mueller-Hinton memberikan hasil jernih. Ketika dilakukan uji konfirmasi pada media agar McConkey, tidak tumbuh koloni bakteri. Hal ini dapat disebabkan oleh karena jumlah bakteri yang didapat kecil dan pertumbuhan yang tidak optimal pada saat inkubasi, mungkin karena efek antimikroba yang masih berlangsung. Selanjutnya pada set 2 konsetrasi klorin $0,05 \%$ terjadi kontaminasi saat melakukan penanaman di media agar McConkey sehingga menyebabkan tumbuhnya koloni bakteri. Pertumbuhan koloni ini berbeda dari kontrol positif. Ada baiknya dilakukan pemeriksaan media yang terkontaminasi untuk mengetahui jenis bakteri yang tumbuh.

Pada konsentrasi klorin 5\%; 2,5\%; 0,5\%, dan $0,05 \%$, bakteri tidak ada yang tumbuh. Hal ini diduga bahwa dalam uji batas konsentrasi klorin masih cukup tinggi, sehingga dalam waktu kontak 5 menit pun bakteri E.coli penghasil ESBL sudah tidak tumbuh, untuk itu dibutuhkan perlakuan pengenceran klorin lebih rendah dari $0,05 \%$ untuk 
waktu kontak lebih dari 5 menit. Hasil penelitian Lima (2015) menunjukkan bahwa uji efektivitas klorin menggunakan konsentrasi $8 \%, 10 \%$, dan $12 \%$ dengan waktu kontak 5, 10, 15, 25, dan 30 menit terhadap bakteri $E$. coli pada disinfeksi permukaan ditemukan bahwa semakin tinggi konsentrasi klorin maka diperlukan waktu kontak yang semakin singkat untuk membunuh bakteri $E$. coli. Penelitian tersebut berbeda dengan penelitian ini karena kontak klorin dan bakteri dilakukan pada permukaan untuk persiapan dan pengolahan makanan seperti kayu. ${ }^{19}$ Permukaan yang kasar memungkinkan bakteri untuk bersembunyi dan menghindar dari paparan disinfeksi klorin. ${ }^{1920}$ Perez (2005) dan Omidbakhsh (2010) melakukan uji efektivitas klorin terhadap endospora Clostridium difficile ( $C$. difficile) dan Bacillus subtilis (B. subtilis) yang dikenal memiliki kemampuan resistensi terhadap bahan kimia. Ditemukan bahwa klorin 0,5\% dengan waktu kontak 10 menit dapat membunuh seluruh endospora, sedangkan pada waktu kontak 1 dan 5 menit, hanya sebagian dari endospora yang tereliminasi. $^{20.21}$ Mekonnen (2015), menemukan pada Mycobacterium tuberculosis, klorin 0,5\% efektif membunuh bakteri dalam waktu 5 menit, sedangkan dengan konsentrasi $0,1 \%$ diperlukan waktu 15 menit atau lebih. ${ }^{22}$ Dari penelian tersebut, maka dapat dinyatakan bahwa semakin rendah konsentrasi klorin, maka waktu kontak yang diperlukan untuk membunuh bakteri juga semakin lama.

Konsentrasi klorin 5\% merupakan konsentrasi yang sering tersedia pada pemutih di pertokoan. Konsentrasi klorin 0,5\% dapat digunakan untuk disinfeksi alat hemolisis dan dekontaminasi. Konsentrasi $0,05 \%$ dapat digunakan juga untuk disinfeksi serta Pusat Pengendalian dan Pencegahan Penyakit Amerika Serikat (Centers for Disease Control and Prevantion/CDC) pada tahun 2019, merekomendasikan sebagai antiseptik saat maraknya kasus infeksi virus Ebola. ${ }^{23}$ Demikian juga daya bunuh atau daya hambat klorin terhadap bakteri dapat dibuktikan dari hasil penelitian ini, yang menunjukkan pada konsentrasi di atas $0,05 \%$ dengan waktu kontak 5 menit sudah mematikan bakteri E. coli penghasil ESBL. Hasil penelitianpenelitian, juga menunjukkan bahwa waktu kontak yang efektif untuk menghambat atau mematikan bakteri berspora, bakteri dengan struktur dinding sel lipid yang tebal, seperti Mycobacterium sp, dan bakteri yang sulit dihambat dan resisten dengan senyawa kimia seperti alkohol atau formalin dapat dilakukan dengan menggunakan klorin.
Hingga saat ini belum ditemukan adanya hubungan cross-resistance antara disinfektan klorin dengan E. coli penghasil ESBL. Namun, cross-resistance memiliki dampak klinik yang cukup besar pada bakteri multi drug resistance (MDR). Alonso-Calleja (2015) menemukan bahwa pada bakteri E. coli yang terpapar disinfektan klorin dengan konsentrasi sub-letal berkontribusi terhadap adaptasi $E$. coli terhadap bahan biosida. Hal ini diduga karena adanya pompa efflux dan perubahan hidrofobisitas pada permukaan sel. ${ }^{24}$ Pompa efflux sendiri dapat bekerja pada berbagai jenis antibiotik lain seperti makrolid, tetrasiklin, dan kuinolon. ${ }^{25}$ Hal ini didukung dengan penemuan Yedekci (2012), yang menyatakan ditemukan pompa efflux pada bakteri E. coli penghasil $E S B L{ }^{26}$

Pada pandemik COVID-19 (Corona virus disease-19), WHO (2020) menyarankan menggunakan klorin dengan konsentrasi $0,1 \%$ untuk disinfeksi permukaan baik pada pusat pelayanan kesehatan ataupun di luar pusat pelayanan kesehatan. Konsentrasi 0,5\% digunakan jika ada kontaminasi materi infeksius yang banyak (10 mL darah/cairan tubuh). ${ }^{27}$

Berdasarkan hasil penelitian ini, efektivitas klorin menghambat bakteri Escherichia Coli penghasil ESBL belum memberikan data yang maksimal, untuk itu sangat diperlukan penelitian lebih lanjut untuk uji yang lebih spesifik, misalnya uji efektifitas klorin terhadap beberapa strain bakteri resisten penghasil ESBL. Selama ini berdasarkan studi literatur yang dilakukan, belum banyak penelitian yang spesifik tentang aktivitas klorin terhadap strain bakteri pengasil ESBL. Hal ini diduga karena berdasarkan waktu kontak 5 menit dengan konsentrasi $5-10 \%$ sudah dapat menghambat stain bakteri yang berspora. ${ }^{21-23,27}$ Mengumpulkan data penelitian melalui beberapa uji efektivitas daya hambat klorin terhadap strain bakteri-bakteri penghasil ESBL dapat membantu masyarakat, untuk memberikan informasi sehingga konsentrasi minimal klorin yang aman (tidak korosif, nonkarsinogenik, dan tidak iritan) untuk dipakai sebagai desinfektan peralatan di rumah sakit atau peralatan rumah tangga.

\section{Simpulan}

Berdasarkan hasil penelitan serta pembahasan, maka dapat disimpulkan bahwa disinfektan klorin dengan konsentrasi $0,05 \%$ dan waktu kontak 5 menit adalah yang paling efektif dalam membunuh bakteri E. coli penghasil ESBL. Penelitian dapat dilakukan ke tahap selanjutnya dengan 
menggunakan konsentrasi klorin yang lebih rendah, dan menggunakan waktu kontak yang lebih cepat.

\section{Daftar Pustaka}

1. Bajaj P, Singh NS, Virdi JS. Escherichia coli $\beta$-lactamases: What really matters. Front Microbiol. 2016;7(MAR):1-14.

2. Blount ZD. The unexhausted potential of $E$. coli. Elife. 2015;4:e05826.

3. Itis.gov. (2020). ITIS Standard Report Page: Escherichia coli. [online] Available at: https://www.itis.gov/servlet/SingleRpt/Single Rpt?search_topic $=$ TSN\&search_value $=285 \&$ print_version $=$ PRT\& $\&$ source $=$ to_print\#null [Accessed 24 Jan. 2020].

4. Parija SC. Textbook of microbiology \& immunology. 2nd ed. India: Elsevier: 2012.

5. Carroll KC, Morse SA, Mietzner T. Miller S, Mikrobiologi kedokteran jawetz, melnick \& adelberg. Edisi ke-27. Jakarta: EGC: 2018.

6. Murray PR, Rosenthal KS, Pfaller MA. Medical microbiology. 8th ed. Philadelphia: Elsevier; 2016.

7. McDonnell G, Russell AD. Antiseptics and disinfectants: activity, action, and resistance [published correction appears in Clin Microbiol Rev 2001 Jan;14(1):227]. Clin Microbiol Rev. 1999;12(1):147-79.

8. Rutala WA, Weber DJ. Uses of inorganic hypochlorite (bleach) in health-care facilities. Clin Microbiol Rev. 1997;10(4):597-610.

9. Peck B, Workeneh B, Kadikoy H, Patel SJ, Abdellatif A. Spectrum of sodium hypochlorite toxicity in man-also a concern for nephrologists. NDT Plus. 2011;4(4):231-5.

10. Ghafourian S, Sadeghifard N, Soheili S, Sekawi Z. Extended spectrum beta-lactamases: Definition, classification and epidemiology. Curr Issues Mol Biol. 2014;17(1):11-22.

11. Tille PM. Bailey and scott's diagnostic micrbiology. 14th edition. St. Louis Missouri: Elsevier; 2017.

12. Anggraini D, Sholihin UH, Savira M, Djojosugito FA, Irawan D, Rustam RP. Prevalensi dan pola sensitivitas enterobacteriaceae penghasil ESBL di RSUD Arifin Achmad Pekanbaru. J Kedokt Brawijaya. 2018;30(1):47.

13. LeChevallier MW, Cawthon CD, Lee RG. Factors promoting survival of bacteria in chlorinated water supplies. Appl Environ Microbiol. 1988;54(3):649-54.

14. Chen YQ, Chen C, Zhang XJ, Zheng Q, Liu
YY. Inactivation of resistant mycobacteria mucogenicum in water: Chlorine resistance and mechanism analysis. Biomed Environ Sci [Internet]. 2012;25(2):230-7.

15. Verspecht T, Rodriguez HE, Khodaparast L, Khodaparast L, Boon N, Bernaerts K, et al. Development of antiseptic adaptation and cross-adapatation in selected oral pathogens in vitro. Sci Rep [Internet]. 2019;9(1):1-13.

16. Reybrouck G. The testing of disinfectants. Int Biodeterior Biodegrad. 1998;41(3-4):269-72.

17. Kampf G, Meyer B, Goroncy-Bermes P. Comparison of two test methods for the determination of sufficient antimicrobial activity of three commonly used alcohol-based hand rubs for hygienic hand disinfection. $\mathrm{J}$ Hosp Infect. 2003;55(3):220-5.

18. Norhan SS, Aymen SY, Aly F, Magdy AA. Quantitative suspension tests for the evaluation of bactericidal, fungicidal and sporicidal effects of biocides used in vaccine production facility. African J Microbiol Res. 2014;8(5):417-24

19. Lima FR, Ahmed S. Activity of disinfectants related to food hygiene and sanitation. North Int Med Coll J. 2015;6(2):64-7.

20. Perez J, Springthorpe VS, Sattar SA. Activity of selected oxidizing microbicides against the spores of Clostridium difficile: Relevance to environmental control. Am J Infect Control. 2005;33(6):320-5.

21. Omidbakhsh N. Evaluation of sporicidal activities of selected environmental surface disinfectants: Carrier tests with the spores of Clostridium difficile and its surrogates. Am J Infect Control [Internet]. 2010;38(9):718-22.

22. Shaikh S, Fatima J, Shakil S, Rizvi SMD, Kamal MA. Antibiotic resistance and extended spectrum beta-lactamases: Types, epidemiology and treatment. Saudi J Biol Sci [Internet]. 2015;22(1):90-101.

23. Cdc.gov. 2019. Rationale and considerations for chlorine use in infection control for nonU.S. general healthcare settings | Non-U.S. general healthcare settings | clinicians | ebola (ebola virus disease) $\mid$ CDC. [online] Available at:

$<$ https://www.cdc.gov/vhf/ebola/clinicians/no n-us-healthcare-settings/chlorine-use.html> [Accessed 16 September 2020].

24. Alonso-Calleja C, Guerrero-Ramos E, AlonsoHernando A, Capita R. Adaptation and crossadaptation of Escherichia coli ATCC 12806 to several food-grade biocides. Food Control [Internet]. 2015;56:86-94. 
25. Thenmozhi S, Moorthy K, Sureshkumar BT, Suresh M. Antibiotic Resistance Mechanism of ESBL Producing Enterobacteriaceae in Clinical Field: A Review. Int J Pure Appl Biosci. 2014;2(3):207-26.

26. Yedekci S, Erac B, Hoşgör Limoncu $M$. Detection of the efflux pump-mediated quinolone resistance in ESBL positive
Escherichia coli and Klebsiella pneumoniae isolates by Phe-Arg-Beta-naphthylamide. Turkish J Pharm Sci. 2012;9(1):67-74.

27. World Health Organization (WHO). Cleaning and disinfection of environmental surfaces in the context of COVID-19: Interim guidance. New York City America: Who. 2020;(May):7. 